\title{
Towards Effective Development of Web-based Business Applications
}

\author{
Azlianor Abdul-Aziz ${ }^{1,2}$, Andy Koronios ${ }^{2}$, Jing $\mathrm{Gao}^{2}$ and \\ Muhammad Suhaizan Sulong ${ }^{1,2}$ \\ ${ }^{1}$ Faculty of Information and Communication Technology, Universiti Teknikal Malaysia Melaka \\ ${ }^{2}$ Strategic Information Management Research Group, University of South Australia, Australia
}

\begin{abstract}
The Internet and the Web continue to evolve at a rapid pace where the Internet as the medium for the Web to provide and share information to global users without boundaries. This has caused the information systems change from standalone desktops to networked systems in order to effectively utilise the Web-specific characteristics for easy access to information anywhere. For this reason, the development of such information systems particularly the ebusiness applications would need to change from traditional development method via software development life cycle to new development methodology through web development life cycle. This new development methodology has been widely used and recognised due to its focus on developing business applications reflecting the nature of the Web. This paper presents a comprehensive review of related literature in which the web development life cycle that considers the unique and special requirements of developing web-based applications with success factors, is more effective compared to the traditional software development. The review findings are taken as a basis for conducting case studies to investigate any issues and challenges from the perspective of web development team.
\end{abstract}

Keywords: Web Development Life Cycle, Web Application Development, e-Business.

\section{Introduction}

With the advent of the web, which was becoming essential parts of our life, the way that software applications are developed through software development life cycle (SDLC) has changed. Web-based business applications gained popularity and widespread acceptance because of its usability in terms of better functionality and mobility (Pearrow 2007) and allowing information linked throughout the globe. Developing web-based business applications with new development methodology, namely web development life cycle (WDLC) is cost effective over desktop applications because it deploys once and then able to access ubiquitously (Smeets et al. 2008). That is why most businesses are building critical business applications that are web-enabled to provide wide accessibility, both internal and external to the organisations (Tipton \& Krause 2009).

Designing and developing complex webbased business applications is a great deal for web developers to ensure its quality (Standing 2005). Most web developers do not realise the significant characteristics and requirements of web-based business applications during the applications development which result in less effective (Murugesan 2008). Thus, there is a need to have understanding about the nature of web-based business application. This paper highlights the uniqueness of web environment in which the characteristics

Copyright (C) 2012 Azlianor Abdul-Aziz, Andy Koronios, Jing Gao and Muhammad Suhaizan Sulong. This is an open access article distributed under the Creative Commons Attribution License unported 3.0, which permits unrestricted use, distribution, and reproduction in any medium, provided that original work is properly cited. Contact author: Azlianor Abdul-Aziz E-mail: aAzlianor.AbdulAziz@postgrads.unisa.edu.au 
and types of web-based business applications are essential for developers to look at prior in building such applications (Mendes et al. 2006). It is important to note that there are special requirements for building such applications that are distinct due to its place in the web environment (Lowe 2002). In addition to effective building web-based business applications, the comprehensive development methodology is necessary that provides detailed processes at each development stage. Furthermore, there are many success factors exist but this paper covers the most out of the authors' best knowledge for developers to consider when building webbased business applications. In summary, ultimately, the development methodology proposed and the success factors revealed would assist the developers in effective building web-based business applications.

The structure of the paper as follows. The first part describes the nature of web- based business applications that show how unique those applications in terms of its characteristics associated with the types of web-based business applications. The special requirements are discussed then that distinct to its nature of web environment. The second part identifies the development methodology and the success factors for effective building webbased business applications for developers to consider. The last part explains the method for further work and draws a conclusion.

\section{Methodology}

The research methodology used in this paper has main activities that focus on identifying the success factors to develop web-based business applications or simply WBA and constructing the development methodology with associated activities, as illustrated in Fig 1.

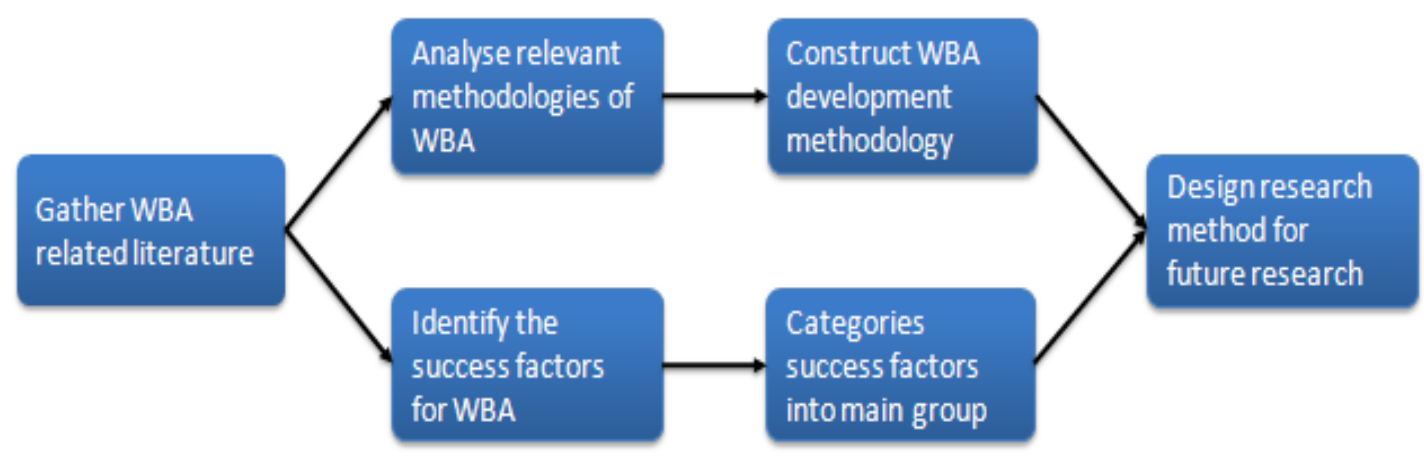

Fig 1. Research Method (Developed for This Study)

Firstly, the research has to gather all related literature of web-based business applications from published journals and conference papers. Secondly, the collected literatures are divided into two parts - the success factors and development methodologies. The success factors for web-based business applications are identified and then categorised the factors into groups; and the relevant methodologies of web-based business applications are analysed to construct the development methodology with associated activities. Finally, the research method for the future research are designed to investigate insightful understanding of issues and challenges that encountered by developers in particular and by web development team in general through conducting case studies.

\section{The Unique Characteristics of Web- based Business Application}

One of the most challenges in building webbased business applications is the dynamic nature of such application. The types of web-based business applications as shown in Fig 2 become more complex and sophisticated as it evolves from documentcentric applications to the knowledgebased applications. The examples for 
document-centric web-based business applications are simple applications and kiosk applications that contain static information and manually updated (Llanos \& Muñoz 2007). Whereas web information systems, search engines and blogs are the examples of interactive web-based business applications in which web users can interact with the application through links and forms (Kappel et al. 2006). More advanced web-based business applications such as adaptive and e-commerce applications are classified as portaloriented and knowledge-based applications. These types of web-based business applications are dynamic, distributed, multimedia and interactive platform for user interaction where it is difficult to maintain (Llanos \& Muñoz 2007). All these web-based business applications types can be used for business-to-business and business-tocustomer applications as well.

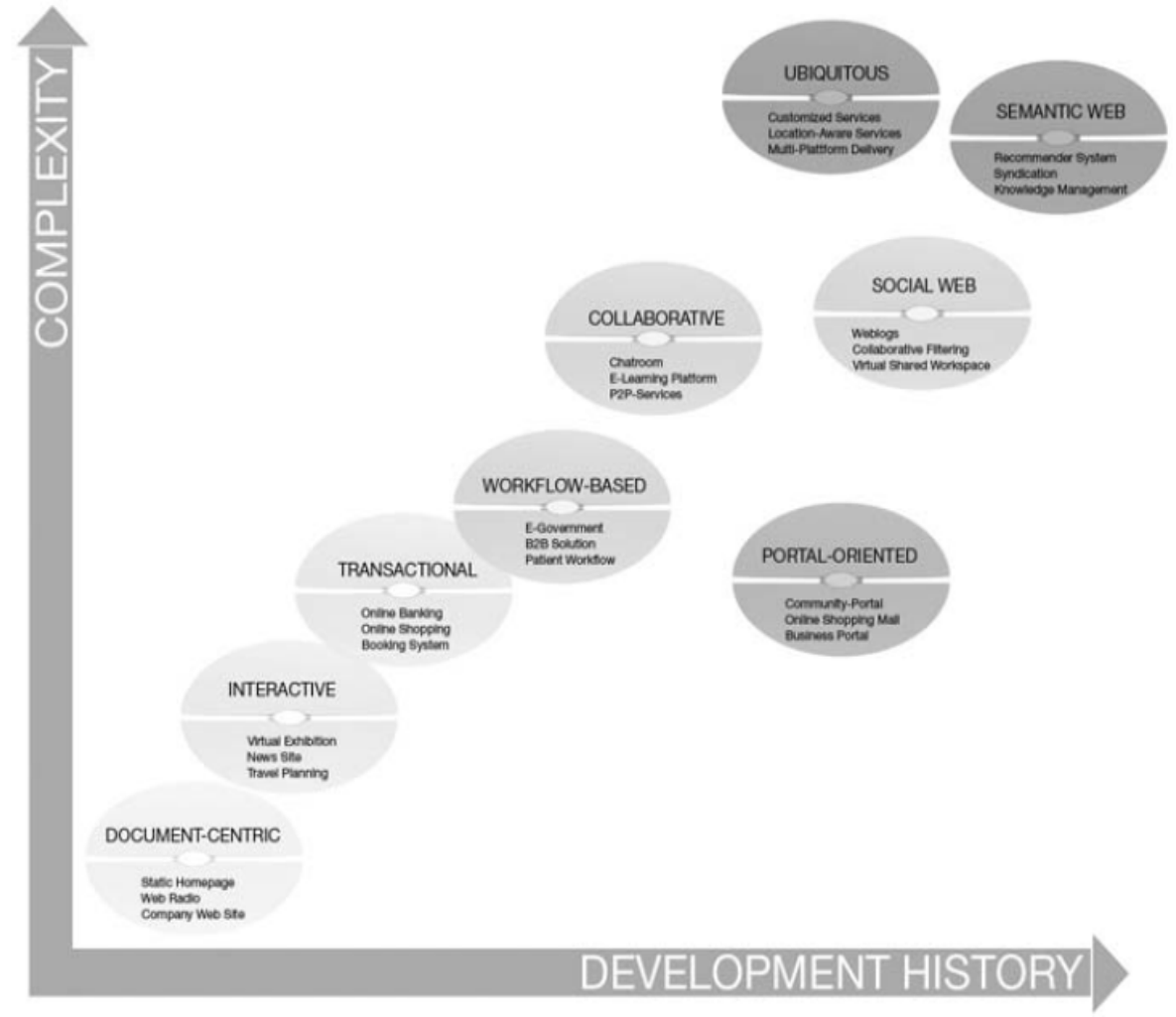

Fig 2. Types of Web-based Business Applications (Adopted from Kappel et al. 2006, p. 5)

Web-based business applications are extensively being used due to the fact that their special nature and characteristics differ from traditional applications. For instance, capability of a web-based business applications runs in different Internet browsers can potentially provide accessibility to anyone anywhere at any time (Kidd \& Chen 2009). Additionally, it provides flexibility and convenience to people and also may be beneficial to organisations for expanding their businesses. Table 1 shows some of the web-based business application characteristics for consideration during the development process that depends on the types of such application. 
Table 1: Characteristic of Web-based Business Applications

\begin{tabular}{|c|c|}
\hline Characteristics & Descriptions \\
\hline $\begin{array}{l}\text { Information } \\
\text { sharing } \\
\text { (Jawadekar, 2004) }\end{array}$ & $\begin{array}{l}\text { Web as a platform of web-based business applications that allow } \\
\text { authorised users to share data and information and collaborate with } \\
\text { others. The applications contain multiple types of data and information } \\
\text { in a standardised format as well as links to other sites that have } \\
\text { additional information such as news, forum, product information, etc. }\end{array}$ \\
\hline $\begin{array}{l}\text { Usability } \\
\text { (Deshpande et al., } \\
\text { 2002) }\end{array}$ & $\begin{array}{l}\text { Ease of use of web-based business applications is the most important } \\
\text { part for web users to browse and navigate through the applications. } \\
\text { Aesthetic design and interactive menus make navigation more intuitive } \\
\text { and user friendly for web users to often visit the web-based business } \\
\text { applications. By having a high level of usability in the web-based } \\
\text { business applications, it gives quick understanding of the application to } \\
\text { web users. }\end{array}$ \\
\hline $\begin{array}{l}\text { Short time } \\
\text { application } \\
\text { delivery } \\
\text { (Murugesan and } \\
\text { Ginige, 2008) }\end{array}$ & $\begin{array}{l}\text { As the number of web-based business applications is in high demand, } \\
\text { web development team continues to develop the applications within fast } \\
\text { paced environments. Having templates and content management } \\
\text { system, web designers and developers can cut short designing and } \\
\text { development time and able to deliver web-based business applications } \\
\text { within short time frames. }\end{array}$ \\
\hline $\begin{array}{l}\text { Continous } \\
\text { evolution (Kappel } \\
\text { et al., 2006) }\end{array}$ & $\begin{array}{l}\text { Web-business applications need to be updated frequently to maintain its } \\
\text { reliability, efficiency and usability to the web users due to rapidly } \\
\text { changing technology. The data and information in web-based business } \\
\text { applications are continuously updated for web users' benefit by having } \\
\text { the most current information possible that would help with making } \\
\text { decisions. }\end{array}$ \\
\hline
\end{tabular}

\section{The Special Requirements of Web-based Business Application}

Focusing to develop web-based business applications by taking care of its special requirements in the whole development life cycle will ensure the best results and performance (Lowe 2002). This is because it addresses the nature of the web as well as its application development environment (Murugesan 2008). Among special requirements are include multilingual, internet browsers, navigational structure and maintenance, but not limited to.

Multilingual Requirement - Web-based business application are developed for universal access and this means there was a concern with respect to the multilingual concepts for easily understandable by global web users (Craven 2006). Thus, language requirements should be seriously considered in the development process (Allen et al. 2006). Although English - as an international language - is suggested to gain wider audience (Zaphiris et al. 2009), offering other several languages might provide better personalisation to web users. This is supported from a study where the top three languages in use by web users for 2010 are English, Chinese and Spanish (Internet World Stats 2011). Web developers need to aware about these special requirements for avoiding future modifications.

Internet Browsers Requirement Internet browser is one of the most important requirements of web-based business applications (Jazayeri 2007). This is because Internet browsers are on the client device and used for views by web users where the end-user interface of webbased business applications is rendered and interpreted (Leff \& Rayfield 2001). Indeed, there are different types of Internet browsers available and they all should be considered during the web-based business application development to ensure it is 
available to web users for accessing desired or intended web-based business applications (Di Lucca \& Fasolino 2006).

Navigational Structure Requirement Another special requirement of web-based business applications is the navigational structure (Gordillo et al. 2006). This navigational structure allows web users to seek desired information by browsing through the web-based business application content (Koch et al. 2008). Without this requirement, it is impossible for web-based business application to deliver intended information as well as for web users to locate desired information (Watrall \& Siarto 2009). Therefore, focusing on the navigation concerns during the development of web-based business applications is critical because it affect the way web users navigate the web applications (Gordillo et al. 2006).

Maintenance Requirement - As webbased business applications require frequently update, it is in fact a need of web maintenance on the information content in order to build web users loyalty - keeping their trust and returning back for future visits (Eldai et al. 2008). The maintenance is done in regular basis that focus on the content and functionality of web-based business applications which sometimes consume several hours or even days (Mendes et al. 2006). Conversely, its different with desktop applications that may have took several months or even years to update the application. Thus, it believed that web-based business application maintenance is on-going processes and plays an important role in order to create well-maintained web applications.

\section{Web-based Business Application Development Methodology}

The Internet grown rapidly in the extent of use creates more opportunities for organisations to improve and enhance their operations on a global scale (Leiner et al. 2009). These can be achieved through access to various web-based business applications ranging from small-scale to large-scale enterprise applications across Internet and the corporate intranets and extranets (Worwa \& Stanik 2010). Examples of such applications are business-to-business and business-tocustomer e-commerce systems, social networking sites, educational and entertainment systems as well as applications that reside in the cloud due to the emergence of cloud computing. Hence, delivering the right information and services to the web user is critical (Reinhartz-Berger et al. 2002). For this reason, it is important for the organisation, mainly developers to realise the development process when building the web-based business applications. It is important to note that there are similar terms referring to a web-based business application such as an internet web application, a web application, web-based information system and a web-based system (Eldai et al. 2008).

The most common development methodology for software-based application is SDLC - software/system development life cycle. However, the way of developing web-based business applications need to consider the dynamic nature and characteristics of the web environment (Al-Salem \& Abu Samaha 2007; Murugesan 2008), and this can be achieved by using WDLC - web development life cycle (Abou-Zahra 2008). Developing web-based business applications seem to have in common with developing software-based applications. Despite the fact that there are similarities in both SDLC and WDLC methodologies, developing web-based business applications using waterfall model of SDLC is likely impractical (Di Lucca \& Fasolino 2006; Murugesan 2008) and thus, WDLC has been widely applied today and remains important for future use.

Many researchers and practitioners including web development organisations define WDLC by stating the steps taken identified as stages. This is true but it seems likely incomplete. Some definitions emphasise that these steps need to meet user requirements and according to individual or business specifications 
(Benny 2007; WebDhoom 2009). Thus, web development life cycle can be defined as a systematic methodology involving a streamlined multi-step process of developing web applications according to specifications and web standards as efficiently as possible.

The development of web-based business applications has been introduced since the birth of World Wide Web and there are many methodologies for developing webbased business applications that have been introduced and practically tested (December 1996; Howcroft \& Carroll 2000; Benny 2007; Abou-Zahra 2008;
WebDhoom 2009; Huang et al. 2010). Each methodology consists of a number of stages which involve a number of different approaches to these stages. Thus, by reviewing the related literature, the most comprehensive methodology for developing web-based business application is Abou Zahra's WDLC stages (2008) named Requirements, Design, Implementation and Operation as illustrated in Fig 3. Each stage is detailed with associated relevant activities, derived from the literature in the following subsections.

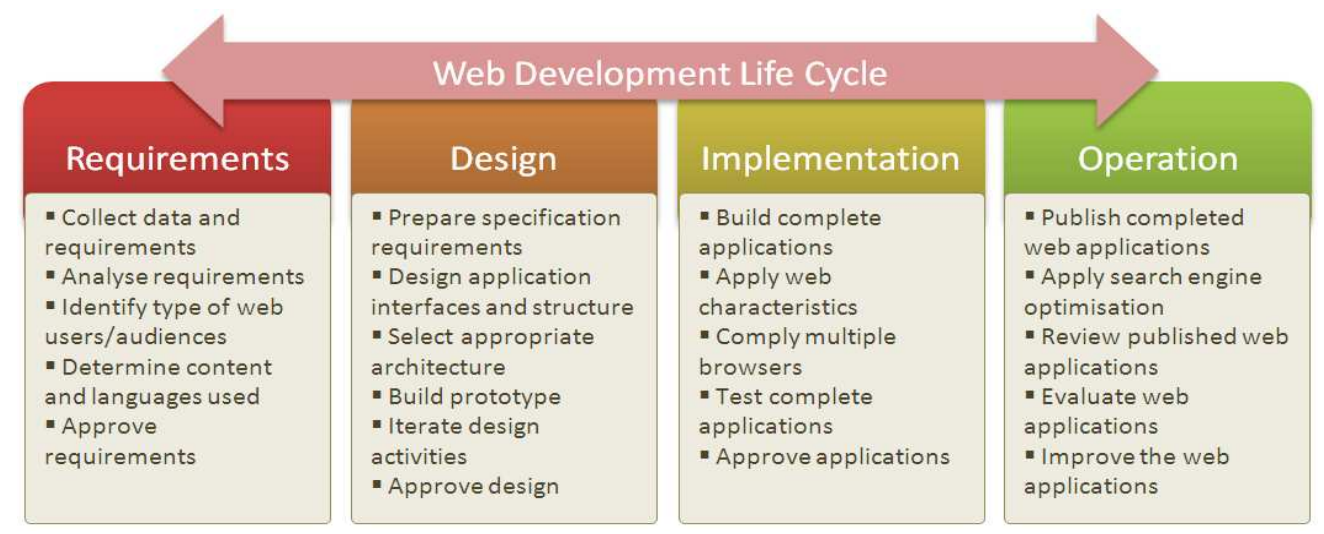

Fig 3. Web Development Life Cycle with Associated Activities (Developed for This Study)

Further elaboration for each stage of the development methodology as follow:-

\section{Requirements Stage}

This is an early stage prior to develop a web-based business application. By and large, the core information about the applications to be developed is happening at this stage. The information will be elicited from the users or clients and described in the requirements document. The information including the type of information, its format and the language used by users or clients (Mendes et al. 2006) and also depending on the webbased business application to be developed. That information will be then capture and analyse to generate a stable requirement which can avoid conflicts and arguments in the near future (Ochoa et al. 2006). At the end of this stage, it will ensure the proposed web-based business application is doable with the capabilities of the organisations and development teams are presented in complete specifications for other stages references. When more information obtained between development team and users, the probability to have a successful web-based business application is higher.

\section{Design Stage}

Designing activities may be considered as one of the significant parts in development life cycle in which it provides a 'skeleton' to the web-based business applications. This is where the designers directly communicate with the users to acquire their aesthetic preferences such as colours and screen layout (Ochoa et al. 2006; Dingsoyr et al. 2010) and site navigation and pluralistic design (Mendes et al. 2006). For instance, a web-based business application that consists of a huge number of pages requires web users to navigate through the entire web-based business 
application by using hyperlinks. All of these aesthetic preferences will accommodate into interface design. Apart from that, database design, architecture design, logical and physical design should be generated in this stage too and documented into design specification requirements. Any necessary changes in the specifications, an iterative process will take place for redesign activities. It is also necessary to have web-based business application prototype that may crystallise that design concept.

\section{Implementation Stage}

This phase involves building the application thoroughly according to the approved design. The activities include creating database, constructing interfaces and implementing codes. Prior to that, one of the important things a developer should consider is the Internet browser. The reason for this is that a web-based business application is dependent on Internet browsers in order to access it (Fraternali et al. 2010) and should works with many different browsers as the Internet users are freely use their preferred browsers. Standard rules and styles of programming and appropriate techniques also should be applied to meet requirements in order to avoid misinterpretation in the future. Testing activities including usability test will be conducted to ensure the web-based business application is free-of-errors and fulfil the usability requirements. The completed web-based business applications also need to be ensured that there is no broken hyperlinks and no difficulty in using highly interactive application. In WDLC, web users' feedback is received after the web-based business application is published, for instance, through online feedback forms.

\section{Operation Stage}

Completed web-based business applications are ready to be published once approval has been made from authorised people. Such applications can be published publicly to a web server either at a web hosting company or at an organisation's own site in order to promote and advertise to potential web users (Russo 2000; WebDhoom 2009). Accordingly, search engine optimisation (SEO) (Rogowski 2007) is applied where it is a significant extension for WDLC phase as based on the characteristic of web-based business application due to involving with the Internet. SEO is introduced to help organisations to be on the top of web searched results. An example of a company that sells personal computer online, this company will be listed on top of the searched result when a web user searches for a personal computer. This can be done by improving web page ranking in search engine listings (Xing \& Lin 2006), keywords or phrases in meta-tags and the number and relevance of links from external sites to the target site (Malaga 2008). Next, maintenance activities involves, evaluating and reviewing webbased business applications in a consistent way for security vulnerabilities and providing recommendation for improvement. As the content of web-based business application is dynamically updated, it must be reliable; for instance should not have broken links for higher accessibility (Russo 2000). Requirements on how to maintain web-based business applications should be clearly stated in the documentation for ease of future modification.

\section{Success Factors for Effective Development}

Success factors have been researched in various studies through case studies and research theories in which in this paper, however, highlights the success factors for effective development from a perspective of web-based business applications environment (Chow \& Cao 2007; Isaías et al. 2009). Relevant literature within the research area of web-based development has been reviewed. As a result, 11 groups of success factors have been derived where each group with associated sub-factors is listed in Table 2. This table does not present an exhaustive list of success factors; it intends to reflect the main groups. 
Table 2: Success Factors for Web-based Business Application Development

\begin{tabular}{|c|c|c|c|}
\hline \multirow{2}{*}{\multicolumn{2}{|c|}{$\begin{array}{l}\text { Success Factor } \\
\text { Management Strategy and Support }\end{array}$}} & \multirow{2}{*}{\multicolumn{2}{|c|}{$\begin{array}{l}\text { Success Factor } \\
\text { Team Environment }\end{array}$}} \\
\hline & & & \\
\hline $\begin{array}{l}\text { - Business orientation } \\
\text { Revenue models }\end{array}$ & $\begin{array}{l}\text { Sulayman \& } \\
\text { Mendes } \\
(2010)\end{array}$ & \multirow[t]{2}{*}{$\begin{array}{l}\text { - Team Competencies and } \\
\text { skills }\end{array}$} & \multirow{2}{*}{$\begin{array}{l}\text { Al-Mudimigh } \\
\text { et al. (2010); } \\
\text { Remus } \\
(2007)\end{array}$} \\
\hline \multirow{2}{*}{$\begin{array}{l}\text { - Top management support } \\
\text { Clear goals and objectives }\end{array}$} & \multirow{2}{*}{$\begin{array}{l}\text { Al-Mudimigh } \\
\text { et al. (2010); } \\
\text { Remus } \\
\text { (2007) }\end{array}$} & & \\
\hline & & $\begin{array}{l}\text { - Leadership involvement } \\
\text { - Employee participation }\end{array}$ & $\begin{array}{l}\text { Sulayman \& } \\
\text { Mendes } \\
(2010)\end{array}$ \\
\hline \multirow[t]{2}{*}{$\begin{array}{l}\text { Definition of clear project } \\
\text { goals }\end{array}$} & \multirow{2}{*}{$\begin{array}{l}\text { Remus \& } \\
\text { Wiener } \\
(2009)\end{array}$} & - Personal characteristics & $\begin{array}{l}\text { Misra et al. } \\
\text { (2009) }\end{array}$ \\
\hline & & \multirow{4}{*}{$\begin{array}{l}\text { - High quality of offshore } \\
\text { employees } \\
\text { - Composition of an } \\
\text { appropriate project team } \\
\text { - Good language abilities of } \\
\text { the offshore employees }\end{array}$} & \multirow{4}{*}{$\begin{array}{l}\text { Remus \& } \\
\text { Wiener } \\
(2009)\end{array}$} \\
\hline - Project motivation & $\begin{array}{l}\text { Mutschler et } \\
\text { al. (2008) }\end{array}$ & & \\
\hline \multicolumn{2}{|c|}{ Project Structure and Management } & & \\
\hline \multirow{2}{*}{$\begin{array}{l}\text { Exploitation of existing } \\
\text { knowledge } \\
\text { - Exploration of new } \\
\text { knowledge }\end{array}$} & \multirow{2}{*}{$\begin{array}{l}\text { Sulayman \& } \\
\text { Mendes } \\
(2010)\end{array}$} & & \\
\hline & & \multirow{7}{*}{$\begin{array}{l}\text { - Team members with high } \\
\text { competence and expertise } \\
\text { - Team members with great } \\
\text { motivation } \\
\text { - Managers knowledgeable } \\
\text { in agile } \\
\text { - Managers who have } \\
\text { adaptive management } \\
\text { style } \\
\text { - Appropriate technical } \\
\text { training to team } \\
\text { - Collocation of the whole } \\
\text { team } \\
\text { - Coherent, self-organising } \\
\text { teamwork } \\
\text { - Projects with small team } \\
\text { - Projects with no multiple } \\
\text { independent teams }\end{array}$} & \multirow[t]{7}{*}{$\begin{array}{l}\text { Chow \& Cao } \\
\text { (2008) }\end{array}$} \\
\hline $\begin{array}{l}\text { - Dedicated resources } \\
\text { - Project management } \\
\text { - Flexible project structure } \\
\text { - Project monitoring and } \\
\text { controlling }\end{array}$ & $\begin{array}{l}\text { Al-Mudimigh } \\
\text { et al. (2010); } \\
\text { Remus } \\
(2007)\end{array}$ & & \\
\hline $\begin{array}{l}\text { - Decision time } \\
\text { - Control }\end{array}$ & $\begin{array}{l}\text { Misra et al. } \\
(2009)\end{array}$ & & \\
\hline $\begin{array}{l}\text { Following agile-oriented } \\
\text { requirement, project and } \\
\text { configuration management } \\
\text { process }\end{array}$ & $\begin{array}{l}\text { Chow \& Cao } \\
\text { (2008) }\end{array}$ & & \\
\hline $\begin{array}{l}\text { Good progress tracking } \\
\text { mechanism }\end{array}$ & & & \\
\hline $\begin{array}{l}\text { Honouring regular } \\
\text { working schedule }\end{array}$ & & & \\
\hline \multirow{3}{*}{$\begin{array}{l}\text { - Availability of process } \\
\text { documentation } \\
\text { - The ability of an } \\
\text { organization to adapt its IT } \\
\text { governance degree of job } \\
\text { redesign }\end{array}$} & \multirow{3}{*}{$\begin{array}{l}\text { Mutschler et } \\
\text { al. (2008) }\end{array}$} & & \\
\hline & & \multicolumn{2}{|c|}{ Culture and Change Management } \\
\hline & & $\begin{array}{l}\text { - Organizational culture } \\
\text { - User training and } \\
\text { education }\end{array}$ & $\begin{array}{l}\text { Al-Mudimigh } \\
\text { et al. (2010); } \\
\text { Remus } \\
(2007)\end{array}$ \\
\hline - Strategic management & $\begin{array}{l}\text { Sen \& Taylor } \\
\text { (2007) }\end{array}$ & - Change management & $\begin{array}{l}\text { Okot-Uma \& } \\
\text { Ssewanyana }\end{array}$ \\
\hline \multicolumn{2}{|c|}{ Information Quality and Management } & & $(2010)$ \\
\hline \multirow{2}{*}{$\begin{array}{l}\text { - Integrity of information } \\
\text { - Richness of content } \\
\text { - Ease of updating and } \\
\text { maintaining information }\end{array}$} & \multirow[t]{2}{*}{$\begin{array}{l}\text { Lee et al. } \\
(2010)\end{array}$} & & $\begin{array}{l}\text { Remus } \\
(2007)\end{array}$ \\
\hline & & $\begin{array}{l}\text { - Corporate culture } \\
\text { - Societal culture }\end{array}$ & $\begin{array}{l}\text { Misra et al. } \\
\text { (2009) }\end{array}$ \\
\hline \multirow{2}{*}{$\begin{array}{l}\text { - Users' inputs } \\
\text { - Availability of content to } \\
\text { justify users' access }\end{array}$} & \multirow{2}{*}{$\begin{array}{l}\text { Isaías et al. } \\
\text { (2009) }\end{array}$} & - Training and learning & \\
\hline & & $\begin{array}{l}\text { Business Process, Requirem } \\
\text { Specification }\end{array}$ & \\
\hline \multirow{2}{*}{$\begin{array}{l}\text { - Reorganization of } \\
\text { information } \\
\text { - Information about existing } \\
\text { processes } \\
\text { - Good documentation }\end{array}$} & \multirow[t]{2}{*}{$\begin{array}{l}\text { Mutschler et } \\
\text { al. (2008) }\end{array}$} & $\begin{array}{l}\text { - Business process } \\
\text { redesigning }\end{array}$ & $\begin{array}{l}\text { Al-Mudimigh } \\
\text { et al. (2010); }\end{array}$ \\
\hline & & $\begin{array}{l}\text { - Preparation of a detailed } \\
\text { project specification }\end{array}$ & $\begin{array}{l}\text { Remus \& } \\
\text { Wiener } \\
(2009)\end{array}$ \\
\hline - Corporate information & Sen \& Taylor & - Ability to redesign & Mutschler et \\
\hline
\end{tabular}




\begin{tabular}{|c|c|c|c|}
\hline competent & $(2007)$ & business processes & al. (2008) \\
\hline $\begin{array}{l}\text { Quality of system and } \\
\text { content }\end{array}$ & $\begin{array}{l}\text { Overhage \& } \\
\text { Thomas } \\
\text { (2003) }\end{array}$ & \multirow{4}{*}{$\begin{array}{l}\text { - } \text { Business process } \\
\text { reengineering } \\
\text { - Requirement Analysis } \\
\text { - Selection of the } \\
\text { - Appropriate } \\
\text { - Software Package } \\
\text { - Portal Strategy } \\
\text { - } \text { Defining the Portal } \\
\text { - Portal Engineering Road } \\
\text { Map }\end{array}$} & \multirow[t]{4}{*}{$\begin{array}{l}\text { Remus } \\
(2007)\end{array}$} \\
\hline \multicolumn{2}{|c|}{ Stakeholders Relationship and Involvement } & & \\
\hline $\begin{array}{l}\text { - Customer satisfaction, } \\
\text { collaboration and } \\
\text { commitment }\end{array}$ & $\begin{array}{l}\text { Misra et al. } \\
\text { (2009) }\end{array}$ & & \\
\hline \multirow{2}{*}{$\begin{array}{l}\text { - Good customer } \\
\text { relationship } \\
\text { - Strong customer } \\
\text { commitment and presence } \\
\text { - Customer having full } \\
\text { authority }\end{array}$} & \multirow[t]{2}{*}{$\begin{array}{l}\text { Chow \& Cao } \\
\text { (2008) }\end{array}$} & & \\
\hline & & $\begin{array}{l}\text { - Appropriate specification } \\
\text { of Web services }\end{array}$ & $\begin{array}{l}\text { Overhage \& } \\
\text { Thomas }\end{array}$ \\
\hline \multirow{2}{*}{$\begin{array}{l}\text { - Available vendor support } \\
\text { for a BPM system }\end{array}$} & \multirow{2}{*}{$\begin{array}{l}\text { Mutschler et } \\
\text { al. (2008) }\end{array}$} & & $(2003)$ \\
\hline & & \multicolumn{2}{|l|}{ Implementation and Delivery } \\
\hline - Customer relations & $\begin{array}{l}\text { Sen and } \\
\text { Taylor } \\
(2007)\end{array}$ & $\begin{array}{l}\text { - Process and application } \\
\text { integration } \\
\text { - Prototyping }\end{array}$ & $\begin{array}{l}\text { Al-Mudimigh } \\
\text { et al. (2010); } \\
\text { Remus }\end{array}$ \\
\hline \multicolumn{2}{|l|}{ Communication Process } & - Portal design & $(2007)$ \\
\hline \multirow[t]{2}{*}{ - Strong Communication } & \multirow{2}{*}{$\begin{array}{l}\text { Al-Mudimigh } \\
\text { et al. (2010); } \\
\text { Remus } \\
(2007)\end{array}$} & $\begin{array}{l}\text { - Aesthetic interface } \\
\text { - Ease of navigation }\end{array}$ & $\begin{array}{l}\text { Lee et al. } \\
(2010)\end{array}$ \\
\hline & & $\begin{array}{l}\text { - Ease of use of component } \\
\text { - Component feedback }\end{array}$ & $\begin{array}{l}\text { Isaías et al. } \\
\text { (2009) }\end{array}$ \\
\hline $\begin{array}{l}\text { Ensuring of a continuous } \\
\text { communication flow }\end{array}$ & $\begin{array}{l}\text { Remus \& } \\
\text { Wiener } \\
(2009)\end{array}$ & $\begin{array}{l}\text { - User content addition } \\
\text { features } \\
\text { - User content development }\end{array}$ & \\
\hline \multirow{2}{*}{$\begin{array}{l}\text { Strong communication } \\
\text { focus with daily face-to- } \\
\text { face meetings }\end{array}$} & \multirow{2}{*}{$\begin{array}{l}\text { Chow \& Cao } \\
\text { (2008) }\end{array}$} & tools & \\
\hline & & $\begin{array}{l}\text { - Delivery strategy } \\
\text { - Pursuing simple design }\end{array}$ & $\begin{array}{l}\text { Chow \& Cao } \\
\text { (2008) }\end{array}$ \\
\hline $\begin{array}{l}\text { Effective corporate } \\
\text { communications }\end{array}$ & $\begin{array}{l}\text { Sen \& Taylor } \\
(2007)\end{array}$ & $\begin{array}{l}\text { - Rigorous refactoring } \\
\text { activities }\end{array}$ & \\
\hline \multicolumn{2}{|c|}{ Controlling and Measuring Performance } & - Correct integration testing & \\
\hline \multirow[t]{2}{*}{ - User acceptance } & \multirow{2}{*}{$\begin{array}{l}\text { Al-Mudimigh } \\
\text { et al. (2010); } \\
\text { Remus } \\
\text { (2007) }\end{array}$} & $\begin{array}{l}\text { - Usability } \\
\text { - Availability of suitable } \\
\text { development tools. }\end{array}$ & $\begin{array}{l}\text { Mutschler et } \\
\text { al. (2008) }\end{array}$ \\
\hline & & - Integrated applications, & Overhage \& \\
\hline \multirow[t]{2}{*}{ - Concern for measurement } & \multirow{2}{*}{$\begin{array}{l}\text { Sulayman \& } \\
\text { Mendes } \\
(2010)\end{array}$} & $\begin{array}{l}\text { technological trends and } \\
\text { technology markets }\end{array}$ & $\begin{array}{l}\text { Thomas } \\
\text { (2003) }\end{array}$ \\
\hline & & Procedure and Standard & \\
\hline \multirow[t]{2}{*}{$\begin{array}{l}\text { - Continuous controlling of } \\
\text { project results }\end{array}$} & \multirow{2}{*}{$\begin{array}{l}\text { Remus \& } \\
\text { Wiener } \\
(2009)\end{array}$} & $\begin{array}{l}\text { Well-defined coding } \\
\text { standards up front }\end{array}$ & $\begin{array}{l}\text { Chow \& Cao } \\
\text { (2008) }\end{array}$ \\
\hline & & - Establish standardized & Overhage \& \\
\hline $\begin{array}{l}\text { Right amount of } \\
\text { documentation }\end{array}$ & $\begin{array}{l}\text { Chow \& Cao } \\
(2008)\end{array}$ & specification frameworks & $\begin{array}{l}\text { Thomas } \\
(2003)\end{array}$ \\
\hline - Efficiency in operation & $\begin{array}{l}\text { Sen \& Taylor } \\
(2007)\end{array}$ & & \\
\hline
\end{tabular}

These factors are necessary to consider in the web-based business applications development and should focus more attention to positively impact such development process. For instance, by having a right amount of documentation, which are relevant and well written, lead to better control and manage the development process (Chow \& Cao 2008).
Additionally, with good development practices and effective communication among team members when developing web-based business applications might increase work productivity and faster delivery (Al-Mudimigh et al. 2010); In this study, therefore, the success factors in the development process of web-based business applications have been identified 
based on the results of the extensive literature analysis and should mainly considered to effectively develop webbased business applications.

\section{Conclusion and Further Research}

This research study attempts to investigate and seek insight understanding about issues related to web-based business applications from developers view point mainly in information quality management. As WDLC may apply differently in organisations, interpretations of business processes for developing web-based business application are vital in order to analyse data from multiple sources and to construct interpretations more efficiently and make conclusions trustworthy. Thus, the interpretive research philosophy with a qualitative approach is used throughout in this research, involving social communication between researchers and participants within phenomenon and context, employing multiple data sources from different organisations (Myers \& Avison 2002; Neuman 2006).

The criteria for organisations to participate in this next study are those provide consultancy services and web-based business application development for other organisations; have a team at least with a three-year minimum experience in developing various web-based business application; and the size of the web-based business application development team can be up to 15 members. The interviewees will include Web Application Programmers, Web Designers, Web Developers, Project Managers, Business Development Consultants, Marketing Professionals and Administration. However, this target group might be changed during the case studies. Approximately 30 to 40 volunteered participants will be interviewed prior to indepth analysis. Based on opportunistic basis, Australian organisations will most probably be selected. The reason for having this above-mentioned criteria was the fact that these organisations might having extensive knowledge and experience of developing web-based business application with best practices. Semi-structured interviews allow flexibility in raising ideas and relevant questions and prompting responses during the interview (Yin 2009).

To conclude, this paper presents the outcomes from a comprehensive literature analysis on the web-based business applications development. The results were presented in which the uniqueness and the special requirements of web-based business application are explained; the development methodology through the web development life cycle in stages associated with activities involved is discussed and the main success factors that derived from multiple sub-factors for consideration during the development of web-based business applications is discovered. The WDLC methodology and the factors presented in this paper will more likely be concerned by and useful to the organisations and developers for effective building web-based business application. Further studies will be carried out to obtain issues and challenges encountered by developers during building the web-based business applications. These studies will be conducted by employing interpretative philosophy after selection of cases. The insight from the development team in looking at how they develop webbased business applications will be analysed. Through this research a preliminary framework will be defined to guide the web-based business application development processes towards enhanced quality of applications. Further development of this framework will be undertaken in the next phase of this research.

\section{Acknowledgement}

This research is funded by the Ministry of Higher Education Malaysia (MOHE), Universiti Teknikal Malaysia Melaka (UTeM) and University of South Australia. We gratefully acknowledge their generous financial support.

\section{References}

Abou-Zahra, S. (2008). "Web Accessibility Evaluation," in Web Accessibility, Springer London, 79-106. 
Allen, M., Currie, L. M., Bakken, S., Patel, V. L. \& Cimino, J. J. (2006), "Heuristic Evaluation of Paper-based Web Pages: A Simplified Inspection Usability Methodology," Journal of Biomedical Informatics, 39 (4), 412-423.

Al-Mudimigh, A. S., Ullah, Z. \& Shahzad, B. (2010), "Critical Success Factors in Implementing Portal: A Comparative Study," Global Journal of Management and Business Research, 10 (2), 129-133.

Al-Salem, L. S. \& Abu Samaha, A. (2007). "Eliciting Web Application Requirements An Industrial Case Study," Journal of Systems and Software, 80 (3), 294-313.

Benny, A. (2007). "Web Site Development Process - The Life Cycle Steps," Macronimous Web Solutions, [Online], [Retrieved January 15, 2012], http://www.macronimous.com/resources /web_development_life_cycle.asp.

Chow, T. \& Cao, D. B. (2008). "A Survey Study of Critical Success Factors in Agile Software Projects," Journal of Systems and Software, 81 (6), 961-971.

Craven, J. (2006). "Web Accessibility: A Review of Research and Initiatives," World Library and Information Congress: 72nd IFLA General Conference and Council.

December, J. (1996). "An Information Development Methodology for the World Wide Web," Technical Communication, 43 (4), 369-375.

Deshpande, Y., Murugesan, S., Ginige, A., Hansen, S., Schwabe, D., Gaedke, M. \& White, B. (2002). 'Web Engineering,' Journal of Web Engineering, 1 (1), 3-17.

Di Lucca, G. A. \& Fasolino, A. R. (2006). "Testing Web-Based Applications: The State of the Art and Future Trends," Information and Software Technology, 48 (12), 1172-1186.

Dingsoyr, T., Dybå, T. \& Moe, N. B. (2010). Agile Software Development: Current Research and Future Directions, SpringerVerlag New York Inc.
Eldai, O. I., Ali, A. H. M. H. \& Raviraja, S. (2008). "Towards a New Methodology for Developing Web-Based Systems," World Academy of Science, Engineering and Technology, 46, 190-195.

Fraternali, P., Rossi, G. \& Sánchez-Figueroa, F. (2010). "Rich Internet Applications," IEEE Internet Computing, 14 (3), 9-12.

Gordillo, S., Rossi, G., Moreira, A., Araujo, J., Vairetti, C. \& Urbieta, M. (2006). "Modeling and Composing Navigational Concerns in Web Applications. Requirements and Design Issues," 25-31.

Howcroft, D. \& Carroll, J. (2000). “A Proposed Methodology for Web Development," Proceedings of the Eighth European Conference on Information Systems, Vienna.

Huang, W., Li, R., Maple, C., Yang, H. J., Foskett, D. \& Cleaver, V. (2010). "A Novel Lifecycle Model for Web-based Application Development in Small and Medium Enterprises," International Journal of Automation and Computing, 7 (3), 389-398.

Internet World Stats (2011), "Top Ten Languages Used in the Web (Number of Internet Users by Language)," Miniwatts Marketing Group, [Online], [Retrieved May 31, 2011],

http://www.internetworldstats.com/stats 7.htm.

Isaías, P., Miranda, P. \& Pífano, S. (2009). "Critical Success Factors for Web 2.0 - A Reference Framework," Online Communities and Social Computing, 5621, 354-363.

Jawadekar, W. (2004). Software Engineering: Principles and Practice, Tata McGraw-Hill Publishing Company Limited, New Delhi.

Jazayeri, M. (2007). "Some Trends in Web Application Development," Future of Software Engineering, 2007. FOSE '07, Minneapolis, 199-213.

Kappel, G, Proll, B, Reich, S. \& Retschitzegger, W. (2006). 'An Introduction 
to Web Engineering,' in Web Engineering: the Discipline of Systematic Development of Web Applications, John Wiley \& Sons Ltd., United Kingdom, 1-21.

Kidd, T. T. \& Chen, I. L. (2009). Wired for learning: An Educator's Guide to Web 2.0, Information Age Publishing Inc., USA.

Koch, N., Knapp, A., Zhang, G. \& Baumeister, H. (2008). "UML-Based Web Engineering: An Approach Based on Standard," Web Engineering: Modelling and Implementing Web Applications, Human-Computer Interaction Series, Springer-Verlag, London, 157-191.

Lee, K., Joshi, K. \& Bae, M. (2010). "Identification of Critical Success Factors (CSF) and their Relative Importance for Web-Based Information Systems Development," Global, Social, and Organizational Implications of Emerging Information Resources Management: Concepts and Applications, IGI Global, New York, 266-279.

Leff, A. \& Rayfield, J. T. (2001). "Webapplication Development Using the Model/View/Controller Design Pattern," 5th IEEE International Enterprise Distributed Object Computing Conference, USA.

Leiner, B. M., Cerf, V. G., Clark, D. D., Kahn, R. E., Kleinrock, L., Lynch, D. C., Postel, J., Roberts, L. G. \& Wolff, S. (2009), "A Brief History of the Internet," ACM SIGCOMM Computer Communication Review, 39 (5), 22-31.

Llanos, C. I. \& Muñoz, M. N. (2007). “Design Guidelines for Web Applications Based on Local Patterns," Proceedings of the 2007 Euro American conference on Telematics and information systems, Faro, Portugal.

Lowe, D. (2002). 'Characterisation of Web Projects,' Proceedings of the 8th Australian World Wide Web Conference, Queensland, Australia.

Malaga, R. A. (2008). "Worst Practices in Search Engine Optimization," Communications of the ACM, 51 (12), 147150.
Mendes, E., Mosley, N. \& Counsell, S. (2006). "The Need for Web Engineering: An Introduction," Web Engineering, Springer Berlin Heidelberg, 1-27.

Misra, S. C., Kumar, V. \& Kumar, U. (2009). "Identifying Some Important Success Factors in Adopting Agile Software Development Practices," Journal of Systems and Software, 82 (11), 1869-1890.

Murugesan, S. (2008). "Web Application Development: Challenges and The Role of Web Engineering," Web Engineering: Modelling and Implementing Web Applications, Springer London, 7-32.

Murugesan, S. \& Ginige, A. (2005), “Web Engineering: Introduction and perspectives," in Web Engineering: Principles and Techniques, W. Suh (ed.). Idea Group Publishing, Hershey, PA.

Mutschler, B., Reichert, M. \& Bumiller, J. (2008). "Unleashing the Effectiveness of Process-Oriented Information Systems: Problem Analysis, Critical Success Factors, and Implications," IEEE Transactions on Systems, Man, and Cybernetics, Part C: Applications and Reviews, 38 (3), 280-291.

Myers, M. D. \& Avison, D. (2002). Qualitative Research in Information Systems: A Reader. Sage Publications, London.

Neuman, W. L. (2006). Social Research Methods: Qualitative and Quantitative Approaches. 6th edn, Pearson/Allyn and Bacon, Boston.

Ochoa, S. F., Pino, J. A., Guerrero, L. A. \& Collazos, C. A. (2006), "SSP: A Simple Software Process for Small-size Software Development Projects," IFIP International Federation for Information Processing, Advanced Software Engineering: Expanding the Frontiers of Software Technology, 219, 94-107.

Okot-Uma, R. W. O. \& Ssewanyana, J. K. (2010). "Building Capacity for Electronic Governance in Developing Countries: Critical Success Factors," E-Agriculture and E-Government for Global Policy 
Development: Implications and Future Directions, 176-190.

Overhage, S. \& Thomas, P. (2003). "WSSpecification: Specifying Web Services Using UDDI Improvements," Web, WebServices, and Database Systems, 2593, 100119.

Pearrow, M. (2007). Web Usability Handbook, 2nd edn, Charles River Media, USA.

Reinhartz-Berger, I., Dori, D. \& Katz, S. (2002), "OPM/Web-Object-Process Methodology for Developing Web Applications," Annals of Software Engineering, 13 (1), 141-161.

Remus, U. (2007). “Critical Success Factors For Implementing Enterprise Portals: A Comparison With ERP Implementations," Business Process Management Journal, 13 (4), 538-552.

Remus, U. \& Wiener, M. (2009). “Critical Success Factors for Managing Offshore Software Development Projects," Journal of Global Information Technology Management, 12 (1), 6-29.

Rogowski, R. (2007). The Business Case for Rich Internet Applications, Best Practices, Forrester Research, Inc.

Russo, N. L. (2000). "Developing Applications for the Web: Exploring Differences between Traditional and World Wide Web Application Development," in Managing Web-Enabled technologies in Organizations: A Global Perspective, Idea Group Publishing, Hershey, USA, 23-35.

Sen, B. \& Taylor, R. (2007). “Determining the Information Needs of Small and Medium-Sized Enterprises: A Critical Success Factor Analysis," Information Research, 12 (4), 12-4.

Smeets, B., Boness, U. \& Bankras, R. (2008). Beginning Google Web Toolkit: From Novice to Professional, Apress, USA.

Standing, C. (2005). "The Requirements of Methodologies for Developing Web
Applications," in Suh, W (ed), WebEngineering: Principles and Techniques, Idea Group Inc, USA, 261-280.

Sulayman, M. \& Mendes, E. (2010). "Quantitative Assessments of Key Success Factors in Software Process Improvement for Small and Medium Web Companies," Proceedings of the 2010 ACM Symposium on Applied Computing, Sierre, Switzerland.

Tipton, H. \& Krause, M. (2009). Information Security Management Handbook, CRC Press, USA.

Watrall, E. \& Siarto, J. (2009). Head First Web Design, O'Reilly Media, Inc., USA.

WebDhoom (2009). "Web Application Development India," WebDhoom, [Online], [Retrieved January 15, 2012], http://www.webdhoom.com/webdevelopment/Software-Development-LifeCycle-(SDLC).html.

Worwa, K. \& Stanik, J. (2010), "Quality of Web-Based Information Systems," Journal of Internet Banking and Commerce, 15 (3).

Xing, B. \& Lin, Z. (2006). "The Impact of Search Engine Optimization on Online Advertising Market," Proceedings of the 8th international conference on Electronic commerce, Fredericton, New Brunswick, Canada, 519-529.

Yin, R. K. (2009). Case Study Research: Design and Methods, 4th (ed), Sage Publications, Thousand Oaks, California.

Zaphiris, P., Pfeil, U. \& Xhixho, D. (2009). "User Evaluation of Age-Centred Web Design Guidelines," Universal Access in Human-Computer Interaction. Addressing Diversity, Springer Berlin / Heidelberg, 677686. 